Karamina, H. • W. Fikrinda

\title{
Aplikasi pupuk organik cair pada tanaman kentang varietas granola di dataran medium
}

\section{Application of liquid organic fertilizer on potato plant varieties of granola in the medium}

Diterima : 15 November 2016/Disetujui : 15 Desember 2016 / Dipublikasikan : 30 Desember 2016

CDepartment of Crop Science, Padjadjaran University

\begin{abstract}
Potato is a horticultural crop with shrub-shaped and sprawled. One of the alternative attempts to improve the results the productivity of potato i.e. potato planting is on the plains of the medium. The purpose of this research is to determine the type and rate of optimum liquid organic fertilizer in increasing the production of potatoes in the medium so that the effectiveness of that expected growth and productivity of potato capable of optimal. This study used a Randomized Block Design with 3 replication with 11 treatment. The results showed that liquid organic fertilizer containing microorganisms streptomycetes with a dose of $25 \mathrm{ml} .1-1$ can increase height growth of plants, number of leaves, stems, and the amount of weight the total plant potatoes. It is clear that the results are best viewed from the observation parameters of growth and harvest.
\end{abstract}

Keywords : Liquid organic fertilizer - Medium land P Productivity

Sari Kentang merupakan tanaman hortikultura dengan berbentuk menyemak dan memiliki sifat menjalar. Salah satu alternative upaya untuk meningkatkan hasil produktivitas kentang yaitu adalah penanaman kentang pada dataran medium. Tujuan dari penelitian ini adalah untuk menentukan jenis dan takaran pupuk organik cair yang optimum dalam meningkatkan produksi kentang di dataran medium sehingga dari efektivitas itulah diharapkan pertumbuhan dan produktivitas kentang mampu optimal. Penelitian ini menggunakan Rancangan Acak Kelompok dengan 3 ulangan dengan 11

Dikomunikasikan oleh Yudithia Maxiselly

Karamina, H. · W. Fikrinda

Jurusan Agroteknologi, Fakultas Pertanian,

Universitas Tribhuwana Tunggadewi

Jl. Telaga warna Tlogomas, 65144 Malang Jawa Timur

Korespondensi email: hidayatikaramina@yahoo.com perlakuan. Hasil penelitian menunjukkan bahwa pupuk organik cair yang mengandung mikroorganisme streptomycetes dengan dosis $25 \mathrm{ml} . \mathrm{l}^{-1}$ mampu meningkatkan pertumbuhan tinggi tanaman, jumlah daun, jumlah batang, dan bobot total tanaman kentang. Hal ini menjelaskan bahwa hasil yang paling baik dilihat dari parameter pengamatan pertumbuhan dan hasil panen.

Kata kunci : Pupuk organik cair · Dataran medium $\cdot$ Produktivitas

\section{Pendahuluan}

Solanum tuberosum atau yang lebih dikenal sebagai kentang adalah tanaman semusim, dengan berbentuk menyemak dan memiliki sifat menjalar. Tanaman ini memiliki peluang pasar yang cukup baik sehingga apabila diusahakan secara serius dapatmeningkatkan pendapatan petani. Menurut Dalmadiyo (2004) produksi kentang masih cukup rendah di dataran tinggi yaitu hanya 10 ton ha-1 sedangkan sebenarnya potensinya sangat tinggi, dapat mencapai 30 ton ha $^{-1}$. Penerapan teknologi maju belum juga sepenuhnya dapat dilakukan secara baik oleh petani, disamping itu prospek pengembangan di dataran tinggi mengalami kendala akibat menurunnya kesuburan tanah dan terbatasnya lahan yang cocok untuk tanaman kentang. Keterbatasan lahan mengakibatkan petani melakukan penanaman pada lereng yang tidak memenuhi syarat karena tingkat kemiringan lahan yang lebih dari $15^{\circ}$ atau tidak boleh ditanami karena akan mengakibatkan longsor.

Salah satu upaya untuk pengembangan kentang adalah menanam pada lahan yang terletak pada dataran medium. Dataran medium dipersyaratkan berada pada ketinggian tempat antara 500-700 mdpl. Pada lahan tersebut 
masalah yang ada adalah apakah kentang mampu untuk berkompetisi dengan tanaman lain yang lebih dahulu ditanam. Hasil penelitian menunjukkan bahwa penanaman tanaman kentang didataran medium memberi prospek cukup baik dari aspek produktivitas yaitu sekitar 20 ton.ha-1 (Sulistiani, 2006).

Produktivitas tinggi akan dicapai apabila tanaman menunjukkan pertumbuhan yang optimal. Kombinasi pupuk anorganik dengan pupuk organik berbentuk padat apabila ditambah pupuk organik cair memberi peluang untuk meningkatkan produksi karena pupuk organik cair akan merangsang pertumbuhan dan menambah jumlah daun yang terbentuk sehingga proses fotosintes akan menghasilkan lebih banyak fotosintat untuk mendukung proses pembentukan dan pengisian umbi (Samadi, 2007).

Diharapkan dengan penanaman kentang pada dataran medium serta pengaplikasikan pupuk organik cair mampu meningkatkan produksi kentang. Penggunaan pupuk organik yang ramah lingkungan dengan sangat mudah terdegradasi di alam serta tidak menimbulkan efek jangka panjang dibandingkan kentang yang diperlakukan pupuk anorganik penuh.

\section{Bahan dan Metode}

Penelitian pada media polybag dan diletakkan di Screen House Nursery Venus Orchid, Desa Tegalwaru, Kecamatan Dau, Kabupaten Malang, berada pada ketinggian tempat $\pm 700 \mathrm{~m}$ dpl dengan suhu rata- rata $23{ }^{\circ} \mathrm{C}$, kelembapan udara rata-rata $75 \%$ dan curah hujan 1000 mm/hari. Penelitian dilaksanakan pada bulan Juli 2016 sampai dengan September 2016. Penelitian dilakukan menggunakan Rancangan Acak Kelompok (RAK) dengan 3 ulangan dan 11 perlakuan.

Perlakuan terdiri dari P0: Pupuk dasar + Tanpa pupuk organik cair, P1 : Pupuk dasar + pupuk organik cair yang mengandung zat Giberelin sebanyak 5 ml.1-1 polybag ${ }^{-1}$, P2 : Pupuk dasar + pupuk organik cair yang mengandung zat Giberelin sebanyak $10 \mathrm{ml}^{-\mathrm{l}^{-1}}$ polybag ${ }^{-1}$, P3 : Pupuk dasar + pupuk organik cair yang mengandung zat Giberelin sebanyak 15 ml.1-1 polybag -1 , P4 : Pupuk dasar + pupuk organik cair yang mengandung zat Giberelin sebanyak $20 \mathrm{ml}^{-1} \mathrm{l}^{-1}$ polybag ${ }^{-1}$, P5 : Pupuk dasar + pupuk organik cair yang mengandung zat Giberelin sebanyak 25 ml.1-1 polybag -1, P6: Pupuk dasar + pupuk organik cair yang mengandung mikroorganisme streptomycetes $5 \mathrm{ml}^{-1} \mathrm{l}^{-1}$ polybag ${ }^{-1}$, P7 : Pupuk dasar + pupuk organik cair yang mengandung mikroorganisme streptomycetes 10 ml.1-1 polybag -1 , P8: Pupuk dasar + pupuk organik cair yang mengandung mikroorganisme streptomycetes $15 \mathrm{ml}^{-\mathrm{l}^{-1}}$ polybag ${ }^{-1}$, P9 : Pupuk dasar + pupuk organik cair yang mengandung mikroorganisme streptomycetes $20 \mathrm{ml}^{-\mathrm{l}^{-1}}$ polybag ${ }^{-1}$, P10 : Pupuk dasar + pupuk organik cair yang mengandung mikroorganisme streptomycetes 25 ml..$^{-1}$ polybag ${ }^{-1}$. Parameter yang diamati adalah tinggi tanaman, jumlah daun, jumlah batang, dan bobot total tanaman kentang. Analisis data menggunakan analisis varian dan dilanjutkan dengan Uji Duncan Multiple Range Test (DMRT).

\section{Hasil dan Pembahasan}

Tinggi tanaman. Hasil analisis data tinggi tanaman kentang seperti tercantum pada Tabel 1 menunjukkan bahwa pemberian pupuk organik cair yang mengandung zat Giberelin dan pupuk organik cair yang mengandung mikroorganisme streptomycetes konsentrasi 5 , 10, 15, 20 dan 25 ml.1-1 memberikan hasil yang berbeda nyata baik pada umur tanaman 14, 28, 42, 56 dan 70 hst. Perlakuan P10 merupakan perlakuan paling baik dikarenakan memiliki tinggi tanaman maksimal disetiap pengamatan pertumbuhan.

Hal ini sesuai dengan pendapat Karyadi 2010, pemanfaatan limbah cair atau pupuk organik cair pada tanaman kentang dapat meminimalisir terjadinya kerusakan tanah serta sebagai sumber energi dan makanan bagi mikroorganisme yang berada di tanah. Pemanfaatan pupuk organik cair juga mampu menambah hara sehingga siklus hara dalam tanah akan baik. Hal ini ditunjan dengan meningkatnya produksi dari tanaman kentang yang dibudidayakan terutama pada peningkatan tinggi tanaman.

Jumlah daun. Hasil pengamatan jumlah daun kentang pada Tabel 2 terlihat bahwa adanya perbedaan hasil dari jumlah daun. Perbedaan tersebut diiringi dengan beda jenis POC yang diaplikasikan serta dosis yang diaplikasikan berbeda. Pada perlakuan pupuk organik cair yang mengandung mikroorganisme streptomycetes menunjukkan bahwa jumlah daun yang dihasilkan adalah yang paling banyak yaitu sejumlah 2,9167 pada umur 14 hst, 30,883 pada umur 28 hst, 32,75 pada umur 42 hst, 33,25 pada umur 56 dan 37,5 pada umur 70 hst. 
Tabel 1. Tinggi Tanaman Kentang pada Beberapa Perlakuan Perbedaan Jenis dan Dosis dari Pupuk Organik Cair.

\begin{tabular}{clllll}
\hline \hline Perlakuan & \multicolumn{5}{c}{ Tinggi tanaman $(\mathrm{cm})$ pada umur $(\mathrm{hst})$} \\
\cline { 2 - 5 } & \multicolumn{1}{c}{ 14 } & 28 & 42 & 56 & 70 \\
\hline P0 & $1,04 \mathrm{~h}$ & $13,85 \mathrm{~g}$ & $15 \mathrm{i}$ & $16,25 \mathrm{~g}$ & $18,19 \mathrm{~h}$ \\
P1 & $1,29 \mathrm{hg}$ & $16,29 \mathrm{fg}$ & $17,08 \mathrm{hi}$ & $18,17 \mathrm{~g}$ & $21,66 \mathrm{gh}$ \\
P2 & $1,41 \mathrm{fgh}$ & $17,35 \mathrm{fg}$ & $18,75 \mathrm{gh}$ & $20,92 \mathrm{f}$ & $22,77 \mathrm{gh}$ \\
P3 & $1,58 \mathrm{efgh}$ & $18,451 \mathrm{ef}$ & $20,11 \mathrm{fg}$ & $21,79 \mathrm{ef}$ & $24,69 \mathrm{fg}$ \\
P4 & $1,79 \mathrm{efg}$ & $19,43 \mathrm{ef}$ & $21,79 \mathrm{ef}$ & $24 \mathrm{de}$ & $27,58 \mathrm{ef}$ \\
P5 & $1,92 \mathrm{def}$ & $21,41 \mathrm{de}$ & $24,17 \mathrm{e}$ & $25,75 \mathrm{~cd}$ & $31 \mathrm{e}$ \\
P6 & $2,08 \mathrm{cde}$ & $24,97 \mathrm{~cd}$ & $26,88 \mathrm{~d}$ & $28,21 \mathrm{c}$ & $32,2 \mathrm{de}$ \\
P7 & $2,5 \mathrm{~cd}$ & $27,09 \mathrm{c}$ & $30,38 \mathrm{c}$ & $32,17 \mathrm{~b}$ & $36,53 \mathrm{~cd}$ \\
P8 & $2,54 \mathrm{c}$ & $27,99 \mathrm{bc}$ & $32,28 \mathrm{bc}$ & $33,75 \mathrm{~b}$ & $38,68 \mathrm{c}$ \\
P9 & $3,42 \mathrm{~b}$ & $30,96 \mathrm{ab}$ & $33,17 \mathrm{~b}$ & $34,68 \mathrm{~b}$ & $43,44 \mathrm{~b}$ \\
P10 & $4,28 \mathrm{a}$ & $33,59 \mathrm{a}$ & $38,03 \mathrm{a}$ & $40,08 \mathrm{a}$ & $50,71 \mathrm{a}$ \\
\hline \hline
\end{tabular}

Keterangan: Angka yang diikuti oleh huruf kecil pada kolom yang sama berbeda nyata pada taraf $5 \%$ menurut Uji Jarak Duncan.

Tabel 2. Jumlah Daun Tanaman Kentang pada Beberapa Perlakuan Perbedaan Jenis dan Dosis dari Pupuk Organik Cair.

\begin{tabular}{|c|c|c|c|c|c|}
\hline \multirow[t]{2}{*}{ Perlakuan } & \multicolumn{5}{|c|}{ Jumlah daun (helai) pada umur (hst) } \\
\hline & 14 & 28 & 42 & 56 & 70 \\
\hline P0 & $0,67 \mathrm{~d}$ & $5,83 \mathrm{f}$ & $8 \mathrm{~d}$ & $8,33 \mathrm{~d}$ & $10,17 \mathrm{~d}$ \\
\hline P1 & $1,17 \mathrm{c}$ & 7,25 ef & $8,25 \mathrm{~d}$ & $8,58 \mathrm{~d}$ & $10,63 \mathrm{~d}$ \\
\hline $\mathrm{P} 2$ & $1,17 \mathrm{c}$ & 10,01 def & $10,92 \mathrm{~d}$ & $11,33 \mathrm{~d}$ & $12,91 \mathrm{~d}$ \\
\hline P3 & $1,42 \mathrm{c}$ & 10,42 def & $11,42 \mathrm{~d}$ & $12 \mathrm{~cd}$ & $13,91 \mathrm{~d}$ \\
\hline $\mathrm{P} 4$ & $1,5 \mathrm{c}$ & 12,73 cdef & $13,67 \mathrm{~cd}$ & $14,42 \mathrm{~cd}$ & $16,71 \mathrm{~d}$ \\
\hline P5 & $1,5 \mathrm{c}$ & 15,25 cde & $16,50 \mathrm{~cd}$ & $16,83 \mathrm{~cd}$ & $18,75 \mathrm{~cd}$ \\
\hline P6 & $1,92 \mathrm{~b}$ & $15,77 \mathrm{~cd}$ & $17,17 \mathrm{bcd}$ & 17,5 bcd & $19,75 \mathrm{~cd}$ \\
\hline P7 & $2,17 b$ & 19,83 bc & 21,17 bc & 21,5 bc & $26,47 \mathrm{bc}$ \\
\hline P8 & $2,17 b$ & $23,75 \mathrm{ab}$ & $26 \mathrm{ab}$ & $26,67 \mathrm{ab}$ & $31 \quad a b$ \\
\hline P9 & $2,67 \mathrm{a}$ & $28,17 \mathrm{a}$ & 20,67 a & $31,25 \mathrm{a}$ & $34,08 \mathrm{ab}$ \\
\hline P10 & $2,92 \mathrm{a}$ & $30,88 \mathrm{a}$ & $32,75 \mathrm{a}$ & $33,25 \mathrm{a}$ & 37,5 a \\
\hline
\end{tabular}

Keterangan: Angka yang diikuti oleh huruf kecil pada kolom yang sama berbeda nyata pada taraf $5 \%$ menurut Uji Jarak Duncan.

Semakin tinggi dosis aplikasi pupuk organik cair maka akan menunjang perkembangan pertumbuhan dari jumlah daun tanaman kentang. Pada penelitian yang dilakukan oleh Dhani, Wardiati dan Rosmini (2013) menyebutkan bahwa pembentukan daun oleh tanaman sangat dipengaruhi oleh ketersediaan unsur hara nitrogen dan fosfor pada media yang tersedia bagi tanaman. Kedua unsur hara tersebut sangat berperan aktif dalam pembentukan sel-sel baru dan komponen penyusun utama senyawa organik dalam tanaman seperti asam amino, asam nukleat, klorofil, ADP dan ATP.

Rao (2004) \& Purwowidodo (1992) menyatakan bahwa pemberian pupuk organik cair pada tanaman kentang mampu mempercepat sintesis asam amino dan protein sehingga mempercepat pertumbuhan jumlah daun tanaman. Pupuk organik cair juga dapat mempercepat pertum- buhan daun jika diaplikasikan dalam konsentrasi yang tinggi namun dengan pemberian secara rutin (Suwandii dan Nurtika, 1987).

Jumlah Batang. Pemberian pupuk organik cair dengan dosis 5, 10, 15, 20 dan $25 \mathrm{ml}^{-\mathrm{l}^{-1}}$ terhadap parameter jumlah batang memberikan hasil yang berbeda nyata. Penambahan jumlah batang maksimum pada umur 70 hst. Perlakuan dengan dosis $25 \mathrm{mll}^{-1}$ jenis pupuk organik cair yang mengandung mikroorganisme streptomycetes memiliki hasil tertinggi pada umur 70 hst yaitu sebesar 9,25. Hal ini diperkuat dengan uji Duncan yang menunjukkan adanya perbedaan yang sangat nyata terhadap masingmasing pemberian pupuk organik cair.

Menurut Indrakusuma, 2000 menyebutkan bahwa pemberian pupuk organik cair yang lengkap kandungan haranya akan menimbulkan laju pertumbuhan yang sintesis secara berbeda- 
Tabel 3. Jumlah Batang Tanaman Kentang pada Beberapa Perlakuan Perbedaan Jenis dan Dosis dari Pupuk Organik Cair.

\begin{tabular}{|c|c|c|c|c|c|}
\hline \multirow[t]{2}{*}{ Perlakuan } & \multicolumn{5}{|c|}{ Jumlah batang (buah) pada umur (hst) } \\
\hline & 14 & 28 & 42 & 56 & 70 \\
\hline P0 & $0,67 \mathrm{~g}$ & $3,5 \mathrm{f}$ & $4,25 \mathrm{~g}$ & $4,33 \mathrm{~g}$ & $4,67 \mathrm{e}$ \\
\hline P1 & $1,08 \mathrm{f}$ & $3,75 \mathrm{f}$ & $4,58 \mathrm{fg}$ & $4,67 \mathrm{fg}$ & 5 de \\
\hline $\mathrm{P} 2$ & $1,08 \mathrm{f}$ & $4,25 \mathrm{f}$ & $5,25 \mathrm{efg}$ & 5,33 efg & 5,75 cde \\
\hline P3 & 1,25 ef & $5,17 \mathrm{e}$ & 5,67 def & 5,75 def & 6,08 cde \\
\hline $\mathrm{P} 4$ & $1,50 \mathrm{de}$ & 5,58 de & 5,92 cde & 6 de & 6,25 bcde \\
\hline P5 & 1,50 de & 5,75 de & 6,08 cde & 6,17 cde & 6,47 bcd \\
\hline P6 & $1,75 \mathrm{~cd}$ & 6 cde & 6,25 cde & 6,33 cde & $6,67 \mathrm{bcd}$ \\
\hline P7 & $1,83 \mathrm{~cd}$ & $6,25 \mathrm{~cd}$ & $6,67 \mathrm{bcd}$ & $6,75 \mathrm{bcd}$ & $7 \quad b c$ \\
\hline P8 & $2 b c$ & $6,83 \mathrm{bc}$ & 7,17 bc & 7,42 bc & $7,83 \mathrm{ab}$ \\
\hline P9 & $2,17 \mathrm{~b}$ & $7,33 \mathrm{ab}$ & $7,58 \mathrm{ab}$ & $7,83 \mathrm{ab}$ & $8,58 \mathrm{a}$ \\
\hline P10 & $2,67 \mathrm{a}$ & $8 \quad a$ & 8,5 a & $8,83 \mathrm{a}$ & $9,25 \mathrm{a}$ \\
\hline
\end{tabular}

Keterangan: Angka yang diikuti oleh huruf kecil pada kolom yang sama berbeda nyata pada taraf $5 \%$ menurut Uji Jarak Duncan.

beda. Pemberian pupuk organik cair pada tanaman kentang diperkirakan akan mempercepat proses sintesis asam amino dan protein sehingga mampu mempercepat pertumbuhan tanaman. Hal ini sesuai dengan pendapat Rao (2004) yang mengatakan bahwa pupuk organik cair yang mengandung mikroorganisme streptomycetes mengandung unsur kalium yang berperan penting dalam setiap proses metabolisme tanaman dan berperan dalam memelihara tekanan turgor dengan maksimal, sehingga memungkinkan proses metabolisme dan menjamin pemanjangan sel pada batang.

Tabel 4. Jumlah Umbi Kentang pada Beberapa Perlakuan Perbedaan Jenis dan Dosis dari Pupuk Organik Cair.

\begin{tabular}{cc}
\hline \hline Perlakuan & Jumlah umbi (buah) \\
\hline P0 & $1,17 \mathrm{e}$ \\
P1 & $1,17 \mathrm{e}$ \\
P2 & $1,33 \mathrm{de}$ \\
P3 & $1,42 \mathrm{de}$ \\
P4 & $1,42 \mathrm{de}$ \\
P5 & $1,5 \mathrm{de}$ \\
P6 & $1,83 \mathrm{cde}$ \\
P7 & $1,92 \mathrm{~cd}$ \\
P8 & $2,33 \mathrm{c}$ \\
P9 & $3,08 \mathrm{~b}$ \\
P10 & $3,75 \mathrm{a}$ \\
\hline \hline
\end{tabular}

Keterangan: Angka yang diikuti oleh huruf kecil pada kolom yang sama berbeda nyata pada taraf 5 \% menurut Uji Jarak Duncan.

Jumlah umbi. Pemberian pupuk organik cair berpengaruh nyata terhadap jumlah umbi. Pemupukan dengan pupuk organik cair yang mengandung mikroorganisme streptomycetes dengan konsentrasi 25 ml.1-1 menghasilkan jumlah umbi yang lebih banyak dibandingkan perlakuan tanaman kontrol. Jumlah umbi yang terbentuk merupakan respon dari ukuran umbi bibit yang digunakan.

Fisher (2002) mengungkapkan bahwa permukaan umbi dan jumlah mata tunas akan mempengaruhi pertumbuhan dari tunas batang yang selanjutnya mempegaruhi jumlah umbi yang terbanyak. Pemberian pupuk organik cair berpengaruh terhadap jumlah umbi yang dihasilkan karena mengandung asam humat dan asam fulfat.

Tabel 5. Bobot Segar Umbi Kentang pada Beberapa Perlakuan Perbedaan Jenis dan Dosis dari Pupuk Organik Cair.

\begin{tabular}{cc}
\hline \hline Perlakuan & Bobot umbi $(\mathrm{g})$ \\
\hline P0 & $77,93 \mathrm{f}$ \\
P1 & $168,20 \mathrm{ef}$ \\
P2 & $191,50 \mathrm{ef}$ \\
P3 & $273,70 \mathrm{de}$ \\
P4 & $306,67 \mathrm{cde}$ \\
P5 & $359,77 \mathrm{~cd}$ \\
P6 & $390,90 \mathrm{bcd}$ \\
P7 & $414,30 \mathrm{bcd}$ \\
P8 & $444,37 \mathrm{bc}$ \\
P9 & $531,17 \mathrm{~b}$ \\
P10 & $725,77 \mathrm{a}$ \\
\hline \hline
\end{tabular}

Keterangan: Angka yang diikuti oleh huruf kecil pada kolom yang sama berbeda nyata pada taraf 5 $\%$ menurut Uji Jarak Duncan.

Bobot segar umbi. Rata-rata bobot segar umbi disajikan pada Tabel 5. Hasil analisis uji Duncan $5 \%$ pada Tabel 5 menunjukkan bahwa perlakuan jenis pupuk organik cair dan dosis 
pemberian pupuk organik cair menghasilkan bobot segar tanaman lebih tinggi yaitu 725,77 g perlakuan P10.

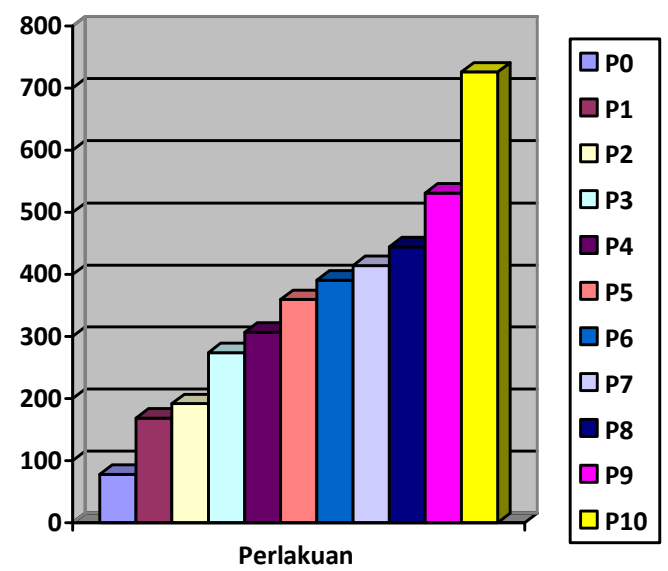

\section{Gambar 1. Bobot Segar Umbi Kentang pada Perlakuan Pupuk Organik Cair.}

Menurut Sumiati (2009) ketersediaan pupuk yang baik mengandung akan unsur hara makro dan mikro dalam keadaan yang cukup merupakan sumber nutrisi sebagai bahan yang mensuplai tanaman dalam bentuk mineral. Islami dan Utomo (2005) menambahkan bahwa semakin tinggi bahan organik tanah maka akan semakin menurunnya kepadatan tanah sehingga pertumbuhan akar tanaman akan berkembang dengan baik. Respon tanaman kentang dalam hal berat basah umbi terhadap pemupukan pupuk organik cair sejalan dengan kondisi pertumbuhan dan perkembangan jumlah daun. Jumlah daun yang disertai penampakan daun yang berwarna hijau menandakan adanya kandungan klorofil yang dapat menghasilkan fotosintat untuk pertumbuhan dan perkembangan tanaman yang pada akhirnya mempengaruhi bobot segar umbi. (Salisbury \& Ross, 1995).

\section{Kesimpulan}

1. Penggunaan pupuk organik cair yang mengandung mikroorganisme streptomycetes dengan dosis 25 ml..$^{-1}$ mampu menghasilkan pertumbuhan yang optimal baik pada parameter pertumbuhan tinggi tanaman, jumlah daun dan jumlah batang

2. Penggunaan pupuk organik cair pada perlakuan (P10) mampu menghasilkan produksi rata-rata bobot segar umbi sebesar $725,77 \mathrm{~g}$ dengan rata-rata jumlah umbi sebanyak 3,75 buah. Bila dikonversi ke hasil produksi per hektar didapatkan hasil 34,56 ton.ha- ${ }^{-1}$ hal ini diatas rata-rata total produksi kentang granola dataran medium secara umum yang hanya 20 ton.ha-1 .

\section{Ucapan Terima Kasih}

Terima kasih kepada Universitas Tribhuwana Tunggadewi telah memberikan kesempatan untuk melaksanakan penelitian. Fakultas Pertanian khususnya Program Studi Agroteknologi tempat dimana penulis mengabdikan diri guna meningkatkan kualitas dan kuantitas. Serta orang tua dan kakak serta suami yang selalu mendukung selesainya penulisan ini.

\section{Daftar Pustaka}

Dhani, H., Wardati, dan Rosmimi. 2013. Pengaruh Pupuk Vermikompos Pada Tanah Inceptisol Terhadap Pertumbuhan dan Hasil Sawi Hijau (Brassica juncea L.). Riau: Universitas Riau. Jurnal Sains dan Teknologi 18 (2), 2013, ISSN: 1412:2391.

Fisher, N. M. dan P. R. Goldsworthy. 2002. Fisiologi Tanaman Budidaya. Penerbit UI Press. Jakarta

Suwandi dan N, Nurtika, 1987. Pengaruh pupuk biokimia "Sari Humus" pada tanaman kubis. Buletin Penelitian Hortikultura 15: 213218

Indrakusuma. 2000. Proposal Pupuk Organik Cair Supra Alam Lestari. PT Surya Pratama Alam. Yogyakarta

Islami T dan Utomo. 2005. Hubungan Tanah, Air dan Tanaman. IKIP Semarang Press. Semarang.

Pooerwowidodo. 1992. Telaah kesuburan tanah. Bandung, Angkasa.

Rao, S. 2004. Mikroorganisme dan Pertumbuhan Tanaman. Univ. Indonesia Jakarta

Salisbury, F. B dan C.W. Ross. 1995. Fisiologi Tumbuhan Jilid 3. Terjemahan oleh Diah R. Lukman dan Sumaryono, 1995. Penerbit ITB, Bandung

Samadi, B. 2007. Kentang dan Analisis Usaha Tani.yogyakarta: Kanisius. p 15

Sumiati, E. 2009.Pertumbuhan dan Hasil Umbi Kentang Kultivar Granola Dengan Aplikasi Mepiquat Klorida di Dataran Medium Maja, Jawa Barat. J.Hort. 9(1):8 - 1 